\title{
South African Winter Rainfall Zone Shifts: A Comparison of Seasonality Metrics For Cape Town From 1841-1899 and 1933-2020
}

Sarah Jane Roffe ( $\nabla$ sarahroffe1@gmail.com)

University of the Witwatersrand https://orcid.org/0000-0003-3683-8377

Jessica Steinkopf

University of the Witwatersrand

Jennifer Fitchett

University of the Witwatersrand

\section{Research Article}

Keywords: Winter rainfall zone drought, Rainfall seasonality, Seasonality score, Wet- and dry-season, Trend analysis, Climate change

Posted Date: November 2nd, 2021

DOI: https://doi.org/10.21203/rs.3.rs-867223/v1

License: @ (i) This work is licensed under a Creative Commons Attribution 4.0 International License. Read Full License

Version of Record: A version of this preprint was published at Theoretical and Applied Climatology on January 4th, 2022. See the published version at https://doi.org/10.1007/s00704-021-03911-7. 


\section{Abstract}

Mounting evidence across South Africa's southwestern winter rainfall zone (WRZ) reflects consistent drying since 1980 and projected trends suggest this will continue. However, limited evidence exists for the region's rainfall seasonality changes. To improve our understanding of these WRZ drying trends, especially within the context of Cape Town's 2015-2017 "Day Zero" drought, it is necessary to explore long-term rainfall seasonality trends. Thus, we use the longest WRZ meteorological record from the South African Astronomical Observatory (SAAO) in Cape Town to investigate rainfall seasonality shifts during $1841-2020$. Consistent with recorded poleward migrations of the subtropical high-pressure belt and mid-latitude westerlies, known drivers behind the drought and drying trends, calculated trends demonstrate strengthening of WRZ conditions, primarily from a later start-date trend leading to a shorter wet-season. Long-term drying trends are quantified for the wet- and dry-seasons, however, analysis of trend evolution reveals much variability, reflecting that drying has only persisted since 1892. Comparative analyses of the first and last 59 years of 1841-2020 reveals a rainfall decline of $\sim 10 \%$ across both seasons - highlighting that the extreme "Day Zero" drought was not only driven by wet-season rainfall declines. Results demonstrate that these drying trends were consistently driven by a long-term decline in rain day counts and a more recent decline in average rainfall per rain day. Correspondence between our results and projected rainfall seasonality trends suggests the trends we quantified will likely continue, thus improvements and continuation of existing water conservation and management strategies are imperative for Cape Town.

\section{Introduction}

The southwestern region of South Africa's winter rainfall zone (WRZ; Fig. 1) experienced below-average rainfall during the 2015-2017 April-September winter wet-seasons, which resulted in the worst drought and water shortages across the region since 1904 (Botai et al. 2017; Wolski 2018). These deficits, which were most pronounced for the autumn (March-May) and spring transition (September-November) seasons, led to supply dam water levels dropping to 20\% capacity during May 2018 (Burls et al. 2019; Pascale et al. 2020). For the $\sim 4$ million inhabitants of the City of Cape Town, this culminated in an imminent threat that dam levels would fall below 10\%, marking the level at which the city's municipal water supply would have been disconnected, before the 2018 winter wet-season (Sousa et al. 2018). The fear surrounding this gathered much attention, with media and municipal authorities terming this event "Day Zero", and forced the city to enforce strict water restrictions, from pre-drought levels of $\sim 200 \mathrm{~L}$ per person per day to 50L per person per day (Muller 2018; Wolski 2018). Fortunately, "Day Zero" was averted as good early winter rains and near-average rainfall for the 2018 winter season led to dam levels rising to $~ 70 \%$ by October 2018 (Sousa et al. 2018; Burls et al. 2019). This crisis highlighted that Cape Town is extremely vulnerable to multi-year droughts, which are expected to increase in frequency and magnitude under anthropogenically induced climate change (Otto et al. 2018; Mahlalela et al. 2019; Pascale et al. 2020).

Many studies have investigated climatological factors driving the 2015-2017 drought. Although poor water-management practices and infrastructure deficiencies exacerbated this water crisis (Muller 2018), the 2015-2017 rainfall deficit was the main driver (Otto et al. 2018; Wolski et al. 2020). Several studies demonstrate that this rainfall deficit, particularly during the transition seasons, corresponds to trends of annual and seasonal rainfall declines, which are more pronounced for recent decades from 1980 (du Plessis and Schloms 2017; Sousa et al. 2018; Mahlalela et al. 2019; Jury 2020; Ndebele et al. 2020; Wolski et al. 2021). Odoulami et al. (2021) demonstrate that the 2015-2017 rainfall deficits correspond to a decrease in winter rain-bearing circulation types, including cold fronts, and an increase in dry circulation types, including the South Atlantic Anticyclone (SAA) and associated ridging anticyclones. These may form part of a trend in changing regional synoptic climatology, quantified by Lennard and Hegerl (2015) to have started in 1979. Moisture transport to the southwestern Cape region and the amount of rain falling on days with rain-bearing circulation types was also demonstrated to be reduced during $2015-2017$ (Odoulami et al. 2021). Burls et al. (2019) found similar results, with a decline, since 1979, in the duration of rainfall events and rainfall amount associated with cold fronts for the April-September winter wet-season. It is established that these changes are linked to hemispheric-scale expansion of the Hadley cell, which has in turn driven a poleward expansion of the subtropical high-pressure belt and a poleward displacement of the westerlies moisture corridor (Sousa et al. 2018; Burls et al. 2019; Mahlalela et al. 2019; Odoulami et al. 2021).

Despite numerous studies exploring rainfall trends and the underlying mechanisms that drove the Cape Town "Day Zero" drought, there is a limited understanding of rainfall seasonality trends, such as wet-season start- and end-date and duration trends, which may have contributed to the occurrence of this drought. To understand this, it is necessary to explore long-term rainfall seasonality changes. Although recent research investigated rainfall seasonality trends for several WRZ locations including Cape Town (Roffe et al. 2021a), the analysis period of 1987-2016 is too short and ends too early to effectively understand how rainfall seasonality trends contributed to driving this drought. Derived from a ratio of monthly rainfall:temperature (Roffe et al. $2021 \mathrm{~b}$ ) and a percentile-based seasonality metric (Roffe et al. 2020) and spanning 1841-2020, we therefore present a long-term rainfall seasonality record for the South African Astronomical Observatory (SAAO) located in Cape Town (Fig. 1), the core region of the drought and WRZ. Using this record, we explore how rainfall seasonality has shifted since 1841 as a means to better understand Cape Town's rainfall seasonality dynamics in relation to the 2015-2017 "Day Zero" water crisis. Given the occurrence of this recent extreme drought and since projections robustly reflect that such droughts will occur more frequently with higher intensity in the future (Pascale et al. 2020), there is a clear need for such a study exploring long-term rainfall seasonality trends as this can inform management strategies for rainfall sensitive activities (e.g. water resource management) across Cape Town.

\section{Study Area: Cape Town's Rainfall Climatology}

While most of South Africa is categorized by a summer rainfall regime, Cape Town is situated within the country's WRZ (Fig. 1; Roffe et al. 2021b). Hence, Cape Town experiences a Mediterranean climate with warm, dry summers and cool, wet winters, receiving $~ 80 \%$ of annual rainfall during extended winter months, from April-September (Mahlalela et al. 2019). Located windward of the Cape Fold Mountain Belt (Fig. 1), Cape Town receives an annual rainfall total

averaging $\sim 600 \mathrm{~mm} . \mathrm{yr}^{-1}$ (Ndebele et al. 2020), which varies interannually in relation to the strength and position of the westerlies - the main winter rainfall moisture source (Sousa et al. 2018). During winter, when the westerlies are situated farther north, mid-latitude cyclone cold fronts, tracking eastwards from the southwest Atlantic Ocean, more frequently reach Cape Town and are responsible for $\sim 89 \%$ of winter rainfall (Burls et al. 2019). Frontless troughs in the westerly wave, which sometimes break-off forming cut-off lows, provide much of the remaining rainfall, primarily during autumn and spring months (Favre et

Page 2/19 
al. 2013; Omar and Abiodun 2020). Long, narrow moisture plumes, termed atmospheric rivers, also produce some of the remaining rainfall (Blamey et al. 2018). As the SAA and westerlies shift south during summer, fewer temperate weather systems reach Cape Town, and warm, dry conditions are promoted by subsidence associated with the SAA (Sousa et al. 2018; Ndarana et al. 2021). SAA ridging anticyclones, occurring year-round but more frequently during warmer months, also typically promote dry summer conditions (Mahlalela et al. 2019; Ndarana et al. 2021). Although the summer period is dry, some rain is delivered to Cape Town from convective storms (Lennard and Hegerl 2015), cut-off lows (Favre et al. 2013), and atmospheric rivers (De Kock et al. 2021).

Winter rainfall across Cape Town displays considerable interannual to interdecadal variability, making it susceptible to dry periods (Dieppois et al. 2016; Sousa et al. 2018; Mahlalela et al. 2019). This is driven by several factors, including anomalies in South Atlantic sea surface temperatures and Southern Ocean sea ice (Reason et al. 2002; Reason and Jagadheesha 2005; Blamey and Reason 2007), and large-scale modes of variability including the Southern Annular Mode (Reason and Rouault 2005; Mahlalela et al. 2019) and El Niño Southern Oscillation (Reason et al. 2000; Philippon et al. 2012). These factors influence the position and strength of the westerlies storm track and associated moisture fluxes to the region (Sousa et al. 2018), which in turn determines rainfall variability primarily through changes in the number and intensity of cold fronts making landfall (Burls et al. 2019).

\section{Data And Methodology 3.1 Data and pre-processing}

Records of daily rainfall and temperature, spanning 1841-1899 and 1933-2020, from the SAAO meteorological station were used to explore rainfall seasonality shifts. Data for 1841-1899 were digitized from meteorological registers held at the SAAO (see Picas et al. 2019; Ndebele et al. 2020). From these registers, sub-daily temperature readings, used to calculate mean daily temperatures, span 1834-1899 (Picas et al. 2019), however, daily rainfall records span 1841-1899 (Ndebele et al. 2020), thus we only use data for the overlapping period 1841-1899. Data for the SAAO for 1933-2020 were obtained from the South African Weather Service (SAWS). Although daily rainfall records span 1900-2020, daily maximum ( $\left.T_{\max }\right)$ and minimum ( $\left.T_{\text {min }}\right)$ temperature records span 1933-2020, thus our analyses only consider data for 1933-2020.

Before performing any statistical analyses, data quality was checked and cleaning was performed where necessary. Details of these processes undertaken for data for 1841-1899 are documented elsewhere (see Picas et al. 2019; Ndebele et al. 2020; Picas and Grab 2020). Given the absence of local rainfall and temperature reference datasets, prior to 1900 , data gaps for 1878-1880 remain. Besides this, the dataset is complete. Before discussing the quality control and cleaning process for data for 1933-2020, note that we followed the process undertaken for 1841-1899 as closely as possible to ensure consistency, and raw data for 1933-2020 were near-complete, with 8\% missing $T_{\max }$ and $T_{\min }$ values and $\sim 5 \%$ missing rainfall values. Initially, dates were checked for temporal consistency and values were rounded to one decimal place for uniformity. Thereafter, raw data were checked to identify errors and outliers. Typographic errors, negative rainfall values, accumulated rainfall values, and where $T_{\min } \geq T_{\max }$ were among the errors identified (Dyson et al. 2009; Durre et al. 2010; Ndebele et al. 2020; Picas and Grab 2020; van der Walt and Fitchett 2020). Outliers were identified using boxplots (for temperature), histograms (for rainfall) and tolerance tests, involving checking for rainfall and temperature values outside upper/lower limits for the SAAO (Aguilar et al. 2003 ; Durre et al. 2010). Once validated, through comparison with surrounding stations records, true erroneous/outlier values were deleted and recorded as missing values. These were estimated or replaced on a daily scale using nearby station records within a $15 \mathrm{~km}$ radius and with a Pearson correlation coefficient value $>0.70$ for existing data (Wolski et al. 2021). Missing temperature data were replaced with data from the closest station, or, if not possible, estimated using a five-day weighted average (Picas and Grab 2020; van der Walt and Fitchett 2020). Missing daily rainfall readings were estimated by a weighted amount, considering the common period rainfall at the SAAO and the nearest station (Ndebele et al. 2020). Estimation was only undertaken for missing SAAO values corresponding to non-zero rainfall values for the nearest station, while all other missing SAAO values were set to zero (Ndebele et al. 2020). Based on a weighted ratio, accumulated rainfall values, labelled by SAWS or identified when large rainfall values followed immediately after missing values, were disaggregated across rain days identified for the closest station (Ndebele et al. 2020).

It is necessary, following data quality control and cleaning, to determine data homogeneity (Aguilar et al. 2003; Wolski et al. 2021). However, due to a lack of metadata, on changes in data collection methods or station relocation for instance, and no suitable reference series prior to 1900 , homogenization was not possible for 1841-1899 (Picas et al. 2019). Thus, homogeneity was not tested.

\subsection{Quantifying rainfall seasonality}

To quantify rainfall seasonality characteristics for the SAAO, a ratio of monthly rainfall:temperature (Roffe et al. 2021b) and a percentile-based wet-season start- and end-date metric (Roffe et al. 2020) were applied using a January-December climatological year. Although numerous metrics have been applied across South Africa (Roffe et al. 2019), these were applied because they accurately characterise and statistically discriminate South African summer-, winterand year-round rainfall regimes (Roffe et al. 2020, 2021b).

Mean monthly rainfall and temperature, calculated using daily rainfall and temperature records, were used to quantify annual seasonality scores (termed score hereafter) following the ratio method (see Roffe et al. 2021b for method details). This score, representing the unitless $m$-coefficient of the least squares linear regression equation, models the relationship between rainfall and temperature, where a negative (positive) relationship corresponds to high rainfall during cooler, winter (warmer, summer) months, and vice versa (Roffe et al. 2021). Resulting scores have positive/negative signs, indicative of seasonality timing, with varying magnitudes quantifying the degree of seasonality, which represents seasonality strength and measures the contrast in length and rainfall amount of wet- and dry-seasons (Roffe et al. 2021b). Based on this, scores are classified as summer-, winter- or year-round rainfall regimes, where scores $<-0.30$ represent WRZ conditions (Roffe et al. 2021b).

Using daily rainfall records, wet- and dry-season characteristics were quantified using a percentile-based wet-season start- and end-date metric (see Roffe et al. 2020, 2021a for method details). Using this metric, summer-, winter- and year-round rainfall regimes are distinguished primarily through the wet-season timing 
and duration, where WRZ conditions are classified when the wet-season is shorter than nine months ( 270 days) and includes the winter solstice, but not the summer solstice (Roffe et al. 2020). For the wet-season, we quantified annual start- and end-dates, length, total rainfall, number of rain days and daily rainfall

rate (Roffe et al. 2020, 2021a). As wet-season start- and end-dates broadly equate to dry-season end- and start-dates, respectively, and can be used to infer the dry-season length, only the dry-season total rainfall, number of rain days and daily rainfall rate were calculated.

\subsection{Analyses for rainfall seasonality shifts}

Rainfall seasonality shifts were analysed through trend and comparative analyses. For all tests, statistical significance was determined using $p$ values, with the alpha level set to $5 \%$.

Trends were calculated for 1841-1899, 1933-2020 and 1841-2020 using the non-parametric Mann-Kendall (MK) trend test with the Sen's slope (ss) estimator, calculating the trend magnitude (Mahlalela et al. 2019; Hekmatzadeh et al. 2020). Considering parametric test assumptions, this test, and all the non-parametric tests discussed below, were applied as they are robust to outliers and have no data distribution assumptions (Hekmatzadeh et al. 2020).

Accounting for the data gap, the non-parametric sequential Mann-Kendall test (SQMKT) was applied only to records spanning 1841-1899 and 1933-2020 to explore the evolution of trends, to determine the start of statistically significant trends if present, and to determine whether change points exist, following George and Athira (2020) and Hekmatzadeh et al. (2020). Using this method, two indicators, termed U(t) and U'(t), are defined based on ranks of the prograde, forward time series and retrograde, backward time series, respectively (Sneyers 1991). Abrupt change points, representing shifts in data distribution properties including the mean and variance (Beaulieu et al. 2012), are identified by plotting $U(t)$ and $U^{\prime}(t)$, where the intersection of the two curves indicates a potential abrupt change point location (Sneyers 1991); changes in the trend direction are also evident from U(t) line direction changes (Hekmatzadeh et al. 2020). Abrupt change points are considered statistically significant when $Z>1.96$ (or <-1.96), and the same applies for trends, however, trends are only statistically significant when this occurs for U(t) values (Sneyers 1991; Hekmatzadeh et al. 2020). Where statistically significant change points exist, trends were additionally calculated, using the abovementioned trend test, for periods before and after the change point (Ndebele et al. 2020).

To determine whether any distinct changes occurred for the rainfall seasonality characteristics, a comparative analysis was performed for the first and last 59 years of the study period, spanning 1841-1899 (historical period: HP) and 1962-2020 (recent period: RP). This was undertaken using the non-parametric Wilcoxon paired samples test (WPST), a test determining whether differences in the distribution and mean exist between two data samples, boxplots and additional descriptive statistics (e.g. standard deviation).

\section{Results}

\subsection{Rainfall seasonality shifts: $1841-2020$}

The MK trend, with the ss estimator, and SQMKT results are presented here for 1841-1899, then 1933-2020, and finally 1841-2020 (Fig. 2, 3, 4, 5, Table 1). Overall, 30 trends were calculated for these periods, with three significant trends quantified for 1841-1899 (Fig. 2), six for 1933-2020 (Fig. 4) and one for 1841-2020 (Fig. 5). The SQMKT results reveal complex and varying patterns of change for the rainfall seasonality variables, demonstrating why relatively few significant trends exist (Fig. 3). For 1841-1899 and 1933-2020, nine abrupt change points exist overall, with five during 1841-1899 and four during 19332020 (Table 1, Fig. 3). Accounting for these, a further 18 trends were quantified and among these ten significant trends exist (Table 1). 
Table 1

Statistically significant change points, detected using the sequential Mann-Kendall (SQMKT) test, for the various rainfall seasonality variables for $1841-1899$ and 1933-2020. Here, ss represents the Sen's slope, z represents the Mann-Kendall statistic and p represents the Mann-Kendall test $p$ value. Statistically significant $p$ values $(p<0.05)$ are denoted in bold.

\begin{tabular}{|c|c|c|c|c|}
\hline Variable & $\begin{array}{l}\text { Statistically significant change } \\
\text { point(s) }(\mathrm{Y} / \mathrm{N})\end{array}$ & $\begin{array}{l}\text { Year of change } \\
\text { point(s) }\end{array}$ & $\begin{array}{l}\text { Trend before change } \\
\text { point(s) }\end{array}$ & $\begin{array}{l}\text { Trend after change } \\
\text { point(s) }\end{array}$ \\
\hline Seasonality score & $\mathrm{N}$ & - & - & - \\
\hline $\begin{array}{l}\text { Wet-season start-date (Julian } \\
\text { day) }\end{array}$ & $\mathrm{N}$ & - & - & - \\
\hline $\begin{array}{l}\text { Wet-season end-date (Julian } \\
\text { day) }\end{array}$ & $\mathrm{Y}$ & 1879 & $\begin{array}{l}s s=0.8, z=1.74, p= \\
0.082\end{array}$ & $\begin{array}{l}s s=-0.6, z=-0.56, p= \\
0.576\end{array}$ \\
\hline Wet-season length (days) & $\mathrm{N}$ & - & - & - \\
\hline Wet-season total rainfall (mm) & Y & 1879 & $\begin{array}{l}s s=2.3, z=1.74, p= \\
0.082\end{array}$ & $\begin{array}{l}s s=-3.5, z=-0.22, p= \\
0.827\end{array}$ \\
\hline Number of wet-season rain days & $\mathrm{N}$ & - & - & - \\
\hline \multirow[t]{2}{*}{$\begin{array}{l}\text { Wet-season daily rainfall rate } \\
\left(\mathrm{mm} \cdot \mathrm{d}^{-1}\right)\end{array}$} & Y & 1879 & $\begin{array}{l}s s=0.1, z=2.47, p= \\
0.013\end{array}$ & $\begin{array}{l}s s=-0.2, z=-1.74, p= \\
0.081\end{array}$ \\
\hline & & 1982 & $\begin{array}{l}s s=0.1, z=2.78, p= \\
0.005\end{array}$ & $\begin{array}{l}\text { ss }=-0.1, z=-2.83, p= \\
0.005\end{array}$ \\
\hline \multirow[t]{2}{*}{ Dry-season total rainfall $(\mathrm{mm})$} & Y & $1879 / 80$ & $\begin{array}{l}s s=0.7, z=1.87, p= \\
0.062\end{array}$ & $\begin{array}{l}\text { ss }=-2.2, z=-1.74, p= \\
0.081\end{array}$ \\
\hline & & $1955 / 56$ & $\begin{array}{l}s s=1.6, z=2.03, p= \\
0.042\end{array}$ & $\begin{array}{l}s s=-0.3, z=-2.03, p= \\
0.042\end{array}$ \\
\hline Number of dry-season rain days & Y & $1949 / 50$ & $\begin{array}{l}s s=1.3, z=1.44, p= \\
0.149\end{array}$ & $\begin{array}{l}s s=-0.1, z=-2.34, p= \\
0.019\end{array}$ \\
\hline \multirow[t]{2}{*}{$\begin{array}{l}\text { Dry-season daily rainfall rate } \\
\left(\mathrm{mm} \cdot \mathrm{d}^{-1}\right)\end{array}$} & Y & $1879 / 80$ & $\begin{array}{l}s s=0.1, z=2.22, p= \\
0.026\end{array}$ & $\begin{array}{l}\text { ss }=-0.1, z=-2.73, p= \\
0.006\end{array}$ \\
\hline & & 1996/97 & $\begin{array}{l}s s=0.1, z=3.82, p= \\
0.0001\end{array}$ & $\begin{array}{l}s s=-0.1, z=-3.75, p= \\
0.0002\end{array}$ \\
\hline
\end{tabular}

The very weak insignificant score trend of $-0.0020 . \mathrm{yr}^{-1}(z=-0.87, p=0.385)$ for $1841-1899$ indicates a tendency towards a stronger degree of seasonality as scores tend away from zero, towards more unevenly distributed rainfall (Fig. 2a). The SQMKT results reflect strong variability, evident from numerous insignificant change points and the highly variable nature of $\mathrm{U}(\mathrm{t})$, thus indicating no clear score trend (Fig. 3a). A reduction (an increase) in the wet-season (dry-season) length similarly reflects a tendency towards a stronger degree of seasonality. This trend of $-0.1 \mathrm{~d} . \mathrm{yr}^{-1}(z=-0.34, p=0.734)$ is similarly weak and insignificant, and numerous insignificant change points with a highly variable nature of $\mathrm{U}(\mathrm{t})$ also indicates strong variability and no clear trend (Fig. $2 \mathrm{~d}$, $3 \mathrm{~d}$ ). This is the case for the very weak insignificant wet-season start- $\left(0.1 \mathrm{~d} . \mathrm{yr}^{-1}, \mathrm{z}=0.35, \mathrm{p}=0.724\right)$ and end-date $\left(0.1 \mathrm{~d}\right.$. $\left.\mathrm{yr}^{-1}, \mathrm{z}=0.81, p=0.420\right)$ trends, reflecting later start- and end-dates (Fig. 2b, c, 3b, c). However, the wet-season end-dates were characterised by a significant change point for 1879 (Fig. $3 c$ ). Despite being weaker than the trend prior to 1878 (given 1878-1880 missing data), the trend towards earlier end-dates $\left(-0.6 \mathrm{~d} . \mathrm{yr} \mathrm{r}^{-1}, \mathrm{z}=-0.56, \mathrm{p}=0.576\right)$ from 1881 , may have, together with the overall later start-date trend, contributed to driving the shorter wet-season trend until 1899 as this trend is more pronounced from 1881 (Fig. 3c, d, Table 1).

For 1841-1899, the wet-season totals increased significantly $\left(2.2 \mathrm{~mm} \cdot \mathrm{yr}^{-1}, z=2.38, p=0.017\right.$; Fig. 2e). A significant change point was detected for 1879 , and a decreasing trend of $-3.5 \mathrm{~mm} \cdot \mathrm{yr}^{-1}(\mathrm{z}=-0.22, \mathrm{p}=0.827)$ was calculated thereafter, despite the significant increasing trend, until 1892 , demonstrated by the $\mathrm{U}(\mathrm{t})$ line (Fig. 3e, Table 1). A decline of $-0.2 d \cdot \mathrm{yr}^{-1}(z=-1.56, p=0.118)$ was quantified for the rain day counts (Fig. 2f). However, this series demonstrates much variability, reflected by numerous insignificant change points and the highly variable nature of $U(t)$, indicating no clear trend (Fig. 3f). A significant increase of $0.1 \mathrm{~mm} \cdot \mathrm{d}^{-1} \cdot \mathrm{yr}^{-1}(\mathrm{z}=2.76, \mathrm{p}=0.006)$ was quantified for the wet-season daily rainfall rate (Fig. $\left.2 \mathrm{~g}\right)$. Though, a significant change point was detected for 1879 , and from 1881-1899 a near-significant (i.e. $p<0.10)$ decreasing trend of $-0.2 \mathrm{~mm} \cdot \mathrm{d}^{-1} \cdot \mathrm{yr}^{-1}(\mathrm{z}=-1.74, \mathrm{p}=0.081)$ was calculated, despite the significant increasing trend until 1892 (Table 1, Fig. 3g).

For 1841/42-1898/99, the dry-season totals increased at a near-significant rate of $0.4 \mathrm{~mm} . \mathrm{yr}^{-1}(\mathrm{z}=1.85, \mathrm{p}=0.064$; Fig. $2 \mathrm{~h})$, however, a significant change point was detected for 1879/80 (Fig. 3h). From 1881/82-1898/99, a near-significant decreasing trend (-2.2mm.yr $\left.{ }^{-1}, z=-1.74, p=0.081\right)$ was calculated (Table 1), despite the significant increasing trend until 1892/93 (Fig. 3h). A near-significant decline of $-0.1 \mathrm{~d} . \mathrm{yr}^{1}(\mathrm{z}=-1.65, \mathrm{p}=0.099)$ was quantified for the dry-season rain day counts (Fig. 2i). Numerous insignificant change points and high variability in the $\mathrm{U}(\mathrm{t})$ line suggests no clear trend, despite a relatively strong $p$ value

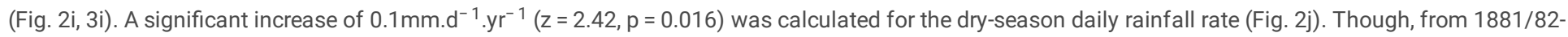
$1898 / 99$, following a significant change point during $1879 / 80$, a significant decreasing trend of $-0.1 \mathrm{~mm}^{-\mathrm{d}^{-1}} \cdot \mathrm{yr} \mathrm{r}^{-1}(\mathrm{z}=-2.73, \mathrm{p}=0.006)$ persisted $($ Table 1$)$, despite a significant increasing trend until 1886/87 (Fig. 3j).

For 1933-2020, the scores consistently tended away from zero, towards more unevenly distributed rainfall and a stronger degree of seasonality, evident from low variability in the SQMKT results and the significant trend of $-0.0038 . \mathrm{yr}^{-1}(\mathrm{z}=-3.41, \mathrm{p}=0.001$; Fig. $3 a, 4 a)$. While the trend for the wet-season length 
demonstrates notable variability (Fig. 3d), the near-significant decreasing trend of $-0.3 d . y r^{-1}(z=-1.66, p=0.097$; Fig. 4d), which indicates a shorter (longer) wet-season (dry-season) duration trend, corresponds to the score trend. The later wet-season start-date trend of $0.3 \mathrm{~d} . \mathrm{yr}^{-1}(\mathrm{z}=2.88, \mathrm{p}=0.004)$ is significant, and is stronger and varies less than the later end-date trend of $0.1 \mathrm{~d} . \mathrm{yr}^{-1}(z=0.70, p=0.484)$, thus the start-date trend was a stronger driver of the declining wet-season duration trend (Fig. 3b, c, 4b, c).

The trend of $-0.5 \mathrm{~mm} \cdot \mathrm{yr}^{-1}(z=-0.90, p=0.368)$ reflects a decline in wet-season totals for 1933-2020, despite being weak overall with notable variability in the $\mathrm{U}(\mathrm{t})$ line (Fig. $3 \mathrm{e}, 4 \mathrm{e})$. The wet-season rain day counts demonstrate little variability and declined at a significant rate of $-0.3 \mathrm{~d} . \mathrm{yr} \mathrm{r}^{-1}(\mathrm{z}=-4.32, \mathrm{p}<0.0001 ; \mathrm{Fig} .3 \mathrm{f}$, 4f). The wet-season daily rainfall rate increased at significant rate of $0.1 \mathrm{~mm} \cdot \mathrm{d}^{-1} \cdot \mathrm{yr} \mathrm{r}^{-1}(z=2.39, p=0.017)$, however, three significant change points exist from $1975-1982$ (Fig. 3g, 4g). Considering the last change point, the wet-season daily rainfall rate decreased at a significant rate of $-0.1 \mathrm{~mm} . \mathrm{d}^{-1} . \mathrm{yr} \mathrm{r}^{-1}(\mathrm{z}=-2.83, \mathrm{p}=$ 0.005) for 1982-2020 (Table 1), despite a significant increasing trend, reflected by the U(t) line for much of 1982-2009 (Fig. 3g).

Although the dry-season totals decreased significantly $\left(-0.3 \mathrm{~mm} \cdot \mathrm{yr}^{-1} ; z=-2.27, p=0.023\right)$ for $1933 / 34-2019 / 20$ (Fig. 4h), according to the SQMKT results, this significant decreasing trend only persisted from $1955 / 56$ at rate of $-0.3 \mathrm{~mm} . \mathrm{yr}^{-1}(\mathrm{z}=-2.03, \mathrm{p}=0.042)$, following a significant increasing trend $\left(1.6 \mathrm{~mm} . \mathrm{yr} \mathrm{r}^{-1} ; \mathrm{z}=\right.$ 2.03, $p=0.042$; Fig. 3h, Table 1). Similarly, while the dry-season rain day counts decreased significantly $\left(-0.1 \mathrm{~d} . \mathrm{yr}^{-1} ; z=-3.43, p=0.001\right)$, this significant decreasing trend only occurred from $1949 / 50$ at a rate of -0.1 d.yr ${ }^{-1}(z=-2.34, p=0.019$; Fig. 3i, 4i, Table 1). The dry-season daily rainfall rate increased at a near-significant rate of $0.1 \mathrm{~mm} \cdot \mathrm{d}^{-1} \cdot \mathrm{yr}^{-1}(z=1.91, \mathrm{p}=0.057)$, however, three significant change points were detected from 1990/91-1996/97 (Fig. 3j, 4j). Again, considering the last change point for $1996 / 97$, the dry-season daily rainfall rate decreased at a significant rate of $-0.1 \mathrm{~mm} . \mathrm{d}^{-1} . \mathrm{yr} \mathbf{r}^{-1}(z=-3.75, p=0.0002)$ for 1996/97-2019/20 (Table 1), despite the significant increasing trend evident from the U(t) line until 2001/02 (Fig. 3j).

Consistent with the score trends detected for 1841-1899 and 1933-2020, the trend for 1841-2020 reflects a decreasing trend of $-0.0006 . y r^{-1}(z=-1.25, p=$ 0.212 ; Fig. $5 \mathrm{a}$ ), indicating that since 1841 the scores have generally tended towards stronger WRZ conditions. The near-significant decreasing trend (-0.1d.yr ${ }^{-1}$; $z=-1.72, p=0.085$ ) for the wet-season length for 1841-2020 is similarly consistent with the decreasing trends for 1841-1899 and 1933-2020 (Fig. 5d). Together with an increasing dry-season length, this also reflects a trend towards stronger WRZ conditions. Notably, the SQMKT results for the scores and wetseason length appear to broadly track each other in direction throughout 1841-2020 (Fig. 3a, d), thus highlighting good agreement between the two methods (Roffe et al. 2021a). The $\mathrm{U}(\mathrm{t})$ line reflects cyclic patterns, with periods of stronger and weaker seasonality (Fig. 3a, d); though further analysis in terms of length and drivers of cycles is beyond this papers scope. The near-significant later wet-season start-date trend of $0.1 \mathrm{~d} . \mathrm{yr}^{-1}(\mathrm{z}=1.82, \mathrm{p}=0.068)$ for $1841-2020$ also corresponds to the trends quantified for 1841-1899 and 1933-2020 (Fig. 5b). No trend exists in the wet-season end-dates for 1841-2020 (Fig. 5c), which corresponds to large variability in the end-dates for 1841-1899 and 1933-2020 (Fig. 3c). This highlights that since 1841, and particularly from 1933, the later start-date trend has primarily driven the shorter wet-season trend. Given this, it is notable that the cyclic patterns reflected by the start-date $\mathrm{U}(\mathrm{t})$ line broadly supports later (earlier) start-dates for periods with shorter (longer) wet-seasons, while relatively little correspondence exists between the end-dates and wet-season length (Fig. 3b, c, d).

Although the wet-season totals trend for $1841-2020$ indicates a near-significant decline of $-0.4 \mathrm{~mm}_{\mathrm{gr}} \mathrm{r}^{-1}(\mathrm{z}=-1.67, \mathrm{p}=0.096$; Fig. $5 \mathrm{e})$, this trend has only persisted since 1881, or more likely since 1892 (Fig. 3e, Table 1). The significant decreasing trend of $-0.1 \mathrm{~d} . \mathrm{yr}^{-1}(\mathrm{z}=-2.52, \mathrm{p}=0.012)$ calculated for the wetseason rain day counts for 1841-2020 corresponds to the decreasing trends quantified for 1841-1899 and 1933-2020 (Fig. 5f). No trend was detected for the wet-season daily rainfall rate for 1841-2020 (Fig. 5g), despite significant increasing trends quantified for 1841-1899 and 1933-2020. This is primarily because the series was characterised by relatively high variability, as is evident from the $\mathrm{U}(\mathrm{t})$ line and numerous significant and non-significant change points (Fig. 3g, Table 1).

While the trend for 1841/42-2019/20 indicates a near-significant decline of $-0.1 \mathrm{~mm} . \mathrm{yr}^{-1}(\mathrm{z}=-1.91, \mathrm{p}=0.056)$ for the dry-season totals (Fig. $5 \mathrm{~h}$ ), this trend has only persisted at a significant rate of $-0.3 \mathrm{~mm}_{\mathrm{yr}} \mathrm{y}^{-1}(z=-2.03, \mathrm{p}=0.042)$ since 1955/56 (Fig. 3h, Table 1). No trend was calculated for $1841 / 42-2019 / 20$ for the dry-season rain day counts and daily rainfall rate (Fig. $5 \mathrm{i}, \mathrm{j})$. Despite a significant decreasing trend of $-0.1 \mathrm{~d} . \mathrm{yr}^{-1}(\mathrm{z}=-2.34, \mathrm{p}=0.019)$ from $1949 / 50$ for the dryseason rain day counts, the no trend result broadly corresponds to relatively high variability evident from the $U(t)$ line for $1841 / 42-1898 / 99$ and the significant change point detected (Fig. 3i, Table 1). For the dry-season daily rainfall rate, this corresponds to high variability throughout 1841-2020, evident from the U(t) line and numerous significant and non-significant change points (Fig. 3j).

Although we do not further explore cyclic patterns for the various rainfall seasonality variables, it is worth noting similarity in trend evolution. This exists between the wet- and dry-season totals (Fig. 3e, h), the wet- and dry-season rain day counts (Fig. 3f, i), and the wet- and dry-season daily rainfall rate (Fig. 3g, j); though there appears to be stronger, more distinct cyclicity for the wet- and dry-season totals. The structure, and specifically the timing, of cyclicity appears to change from the earlier (1841-1899) to later period (1933-2020); a result which is similarly evident for SAAO annual and seasonal rainfall totals (Ndebele et al. 2020). As such, the similarity in trend structure across the wet- and dry-seasons highlights that despite differences in their timing, there is much similarity in their rainfall characteristics and trends.

\subsection{Statistically comparing historical (1841-1899) and recent (1962-2020) period rainfall seasonality characteristics}

Significant mean and data distribution differences in the various rainfall seasonality variables for 1841-1899 (HP) and 1962-2020 (RP) were calculated, using the WPST, for the wet-season rainfall totals and rain day counts and the dry-season rainfall totals (Fig. $6 \mathrm{e}, \mathrm{f}, \mathrm{h}$ ). For the remaining variables, the differences are insignificant (Fig. 6a, b, c, d, g, i, j). Despite this, data distribution differences exist between the HP and RP for most variables - evident from visual inspection of the boxplots, focusing mainly on the interquartile range (IQR), representing the behaviour and spread of most data values, and mean and 
median values (Fig. 6). Notwithstanding the statistical significance level, the differences detected generally agree with trend results for $1841-2020$ (Fig. 5, 6 , Table 2), reflecting that the mean and data distribution differences broadly represent the results of these trends. 
Table 2

Descriptive statistics of rainfall seasonality characteristics for the historical (1841-1899) and recent (1962-2020) periods. HP and RP denote statistics for the historical and recent periods, respectively.

\begin{tabular}{|c|c|c|c|c|c|c|c|c|c|c|c|}
\hline Variable & Minimum & $\begin{array}{l}\text { First } \\
\text { Quartile }\end{array}$ & Median & Mean & $\begin{array}{l}\text { Third } \\
\text { Quartile }\end{array}$ & Maximum & $\begin{array}{l}\text { Interquartile } \\
\text { range }\end{array}$ & Range & $\begin{array}{l}\text { Standard } \\
\text { deviation }\end{array}$ & $\begin{array}{l}\text { Coefficient } \\
\text { of } \\
\text { variation } \\
\text { (\%) }\end{array}$ & Skewness \\
\hline $\begin{array}{l}\text { HP } \\
\text { seasonality } \\
\text { score }\end{array}$ & -2.00 & -1.39 & -1.16 & -1.21 & -1.02 & -0.56 & 0.37 & 1.44 & 0.28 & 23.1 & -0.27 \\
\hline $\begin{array}{l}\text { RP } \\
\text { seasonality } \\
\text { score }\end{array}$ & -2.17 & -1.35 & -1.19 & -1.23 & -1.06 & -0.46 & 0.29 & 1.71 & 0.30 & 24.3 & -0.77 \\
\hline $\begin{array}{l}\text { HP start- } \\
\text { date } \\
\text { (Julian } \\
\text { day) }\end{array}$ & $\begin{array}{l}4 \text { January } \\
\text { (4) }\end{array}$ & $\begin{array}{l}20 \text { March } \\
(79)\end{array}$ & $\begin{array}{l}\text { 11 April } \\
(101)\end{array}$ & $\begin{array}{l}3 \text { April } \\
\text { (93) }\end{array}$ & $\begin{array}{l}23 \text { April } \\
(113)\end{array}$ & $\begin{array}{l}25 \text { May } \\
(145)\end{array}$ & 34 & 141 & 30 & 32.0 & -1.32 \\
\hline $\begin{array}{l}\text { RP start- } \\
\text { date } \\
\text { (Julian } \\
\text { day) }\end{array}$ & $\begin{array}{l}5 \text { February } \\
(36)\end{array}$ & $\begin{array}{l}24 \text { March } \\
(83)\end{array}$ & $\begin{array}{l}\text { 17 April } \\
\text { (107) }\end{array}$ & $\begin{array}{l}11 \text { April } \\
\text { (101) }\end{array}$ & $\begin{array}{l}18 \text { April } \\
\text { (118) }\end{array}$ & $\begin{array}{l}26 \text { May } \\
(146)\end{array}$ & 35 & 110 & 27 & 26.6 & -0.59 \\
\hline $\begin{array}{l}\text { HP end- } \\
\text { date } \\
\text { (Julian } \\
\text { day) }\end{array}$ & $\begin{array}{l}8 \\
\text { September } \\
(251)\end{array}$ & $\begin{array}{l}28 \\
\text { September } \\
\text { (271) }\end{array}$ & $\begin{array}{l}10 \\
\text { October } \\
(283)\end{array}$ & $\begin{array}{l}12 \\
\text { October } \\
\text { (285) }\end{array}$ & $\begin{array}{l}23 \\
\text { October } \\
(296)\end{array}$ & $\begin{array}{l}30 \\
\text { November } \\
(334)\end{array}$ & 25 & 83 & 21 & 7.5 & 0.50 \\
\hline $\begin{array}{l}\text { RP end- } \\
\text { date } \\
\text { (Julian } \\
\text { day) }\end{array}$ & $\begin{array}{l}10 \text { August } \\
(222)\end{array}$ & $\begin{array}{l}23 \\
\text { September } \\
(266)\end{array}$ & $\begin{array}{l}11 \\
\text { October } \\
(284)\end{array}$ & $\begin{array}{l}10 \\
\text { October } \\
\text { (283) }\end{array}$ & $\begin{array}{l}1 \\
\text { November } \\
(305)\end{array}$ & $\begin{array}{l}8 \\
\text { December } \\
(342)\end{array}$ & 39 & 120 & 28 & 9.9 & -0.08 \\
\hline $\begin{array}{l}\text { HP wet- } \\
\text { season } \\
\text { length } \\
\text { (days) }\end{array}$ & 139 & 168 & 192 & 194 & 218 & 294 & 50 & 155 & 33 & 17.1 & 0.49 \\
\hline $\begin{array}{l}\text { RP wet- } \\
\text { season } \\
\text { length } \\
\text { (days) }\end{array}$ & 115 & 159 & 184 & 183 & 209 & 240 & 50 & 125 & 32 & 17.5 & -0.15 \\
\hline $\begin{array}{l}\text { HP wet- } \\
\text { season } \\
\text { total } \\
\text { rainfall } \\
(\mathrm{mm})\end{array}$ & 387.2 & 460.7 & 518.2 & 536.9 & 598.0 & 871.8 & 137.3 & 484.6 & 106.4 & 19.8 & 0.83 \\
\hline $\begin{array}{l}\text { RP wet- } \\
\text { season } \\
\text { total } \\
\text { rainfall } \\
(\mathrm{mm})\end{array}$ & 282.1 & 387.5 & 486.9 & 481.8 & 558.5 & 793.5 & 171.0 & 511.4 & 118.8 & 24.6 & 0.43 \\
\hline $\begin{array}{l}\text { HP number } \\
\text { of wet- } \\
\text { season } \\
\text { rain days }\end{array}$ & 50 & 61 & 68 & 70 & 75 & 105 & 14 & 55 & 12 & 16.9 & 0.79 \\
\hline $\begin{array}{l}\text { RP number } \\
\text { of wet- } \\
\text { season } \\
\text { rain days }\end{array}$ & 43 & 57 & 63 & 64 & 72 & 92 & 15 & 49 & 11 & 16.6 & 0.14 \\
\hline $\begin{array}{l}\text { HP wet- } \\
\text { season } \\
\text { daily } \\
\text { rainfall rate } \\
\left(\mathrm{mm} \cdot \mathrm{d}^{-1}\right)\end{array}$ & 4.1 & 6.4 & 7.6 & 7.9 & 9.0 & 12.9 & 2.6 & 8.8 & 2.0 & 25.3 & 0.61 \\
\hline $\begin{array}{l}\text { RP wet- } \\
\text { season } \\
\text { daily } \\
\text { rainfall rate } \\
\left(\mathrm{mm} \cdot \mathrm{d}^{-1}\right)\end{array}$ & 4.4 & 6.2 & 7.3 & 7.7 & 8.8 & 13.7 & 2.6 & 9.3 & 2.1 & 26.7 & 0.75 \\
\hline $\begin{array}{l}\text { HP dry- } \\
\text { season } \\
\text { total } \\
\text { rainfall } \\
(\mathrm{mm})\end{array}$ & 37.1 & 99.1 & 110.6 & 113.2 & 126.4 & 161.8 & 27.3 & 124.7 & 24.1 & 21.3 & -0.42 \\
\hline
\end{tabular}




\begin{tabular}{|c|c|c|c|c|c|c|c|c|c|c|c|}
\hline Variable & Minimum & $\begin{array}{l}\text { First } \\
\text { Quartile }\end{array}$ & Median & Mean & $\begin{array}{l}\text { Third } \\
\text { Quartile }\end{array}$ & Maximum & $\begin{array}{l}\text { Interquartile } \\
\text { range }\end{array}$ & Range & $\begin{array}{l}\text { Standard } \\
\text { deviation }\end{array}$ & $\begin{array}{l}\text { Coefficient } \\
\text { of } \\
\text { variation } \\
(\%)\end{array}$ & Skewness \\
\hline $\begin{array}{l}\text { RP dry- } \\
\text { season } \\
\text { total } \\
\text { rainfall } \\
(\mathrm{mm})\end{array}$ & 59.6 & 87.6 & 103.0 & 104.2 & 120.3 & 156.9 & 32.7 & 97.3 & 22.3 & 21.4 & 0.20 \\
\hline $\begin{array}{l}\text { HP number } \\
\text { of dry- } \\
\text { season } \\
\text { rain days }\end{array}$ & 12 & 24 & 30 & 29 & 36 & 49 & 12 & 37 & 9 & 30.0 & 0.11 \\
\hline $\begin{array}{l}\text { RP number } \\
\text { of dry- } \\
\text { season } \\
\text { rain days }\end{array}$ & 12 & 23 & 27 & 27 & 33 & 43 & 10 & 31 & 7 & 26.1 & 0.09 \\
\hline $\begin{array}{l}\text { HP dry- } \\
\text { season } \\
\text { daily } \\
\text { rainfall rate } \\
\left(\mathrm{mm} \cdot \mathrm{d}^{-1}\right)\end{array}$ & 2.0 & 3.2 & 3.8 & 4.2 & 5.0 & 9.3 & 1.8 & 7.3 & 1.7 & 40.3 & 1.22 \\
\hline 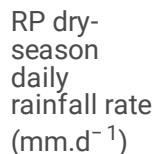 & 2.0 & 3.2 & 3.7 & 4.1 & 4.6 & 9.2 & 1.4 & 7.2 & 1.4 & 34.7 & 1.42 \\
\hline
\end{tabular}

The mean ( $\mathrm{HP}=-1.21, \mathrm{RP}=-1.23)$ and median ( $\mathrm{HP}=-1.16, \mathrm{RP}=-1.19)$ score values reflect slightly stronger RP scores (Fig. 6a, Table 2), indicating a shift towards a slightly stronger degree of seasonality for the RP. This corresponds to a shorter (longer) RP wet-season (dry-season) length, supported by the plotted IQR and smaller RP minimum (HP = 139 days, $R P=115$ days), mean ( HP = 194 days, RP = 183 days), median (HP = 192 days, $R P=184$ days $)$ and maximum $(H P=294$ days, $R P=240$ days) values (Fig. 6d, Table 2). Although notable differences exist in the distribution of the HP and RP wet-season end-date datasets, particularly reflected by larger interannual variability ( $\mathrm{HP}$ coefficient of variability $[\mathrm{CV}]=7.5 \%, \mathrm{RP} C V=9.9 \%)$ and larger $\mathrm{IQR}(\mathrm{HP}=25$ days, RP $=39$ days $)$ values for the RP, the mean (HP = 12 October, Julian day [JD] = 285, RP = 10 October, JD = 283) and median (HP = 10 October, JD = 283, RP = 11 October, JD = 284) values are very similar and reflect little to no end-date shift (Fig. 6c, Table 2). This confirms that the wet-season (and dry-season) duration shift is primarily due to later RP wet-season start-dates, evident from the plotted IQR, and later RP mean (HP = 3 April, JD = 93, RP = 11 April, JD = 101) and median (HP = 11 April, $J D=101, R P=17$ April, JD = 107) values (Fig. 6b, Table 2).

Besides the wet-season timing shifts, changes occurred in the magnitude and intensity of wet-season rainfall, and rain day counts. The HP wet-season was wetter than the RP wet-season (Fig. 6e, f, g, Table 2). Most ( 70\%) annual HP wet-season totals were higher than for the RP, evident from the plotted IQR, and the minimum $(\mathrm{HP}=387.2 \mathrm{~mm}, \mathrm{RP}=282.1 \mathrm{~mm})$, mean $(\mathrm{HP}=536.9 \mathrm{~mm}, \mathrm{RP}=481.8 \mathrm{~mm})$, median $(\mathrm{HP}=518.2 \mathrm{~mm}, \mathrm{RP}=486.9 \mathrm{~mm})$ and $\mathrm{maximum}(\mathrm{HP}=871.8 \mathrm{~mm}$, $\mathrm{RP}=793.5 \mathrm{~mm}$ ) values (Fig. 6e, Table 2). The wet-season rain day counts were lower for the RP compared to the HP, as demonstrated by the plotted IQR, and the minimum ( $\mathrm{HP}=50$ days, $\mathrm{RP}=43$ days), mean ( $\mathrm{HP}=70$ days, $\mathrm{RP}=64$ days), median ( $\mathrm{HP}=68$ days, $\mathrm{RP}=63$ days $)$ and maximum $(\mathrm{HP}=105$ days, $\mathrm{RP}=92$ days) values (Fig. 6f, Table 2). Compared to the HP, the RP wet-season daily rainfall rate was slightly reduced, evident from the plotted IQR, and the mean (HP $\left.=7.9 \mathrm{~mm} \cdot \mathrm{d}^{-1}, \mathrm{RP}=7.7 \mathrm{~mm} \cdot \mathrm{d}^{-1}\right)$ and median $\left(\mathrm{HP}=7.6 \mathrm{~mm} \cdot \mathrm{d}^{-1}, \mathrm{RP}=7.3 \mathrm{~mm} \cdot \mathrm{d}^{-1}\right)$ values (Fig. $6 \mathrm{~g}$, Table 2).

Changes also occurred in the magnitude and intensity of dry-season rainfall, and the rain day counts, with the HP dry-season wetter than the RP dry-season (Fig. 6h, i, j, Table 2). The plotted IQR, and mean (HP=113.2mm, RP $=104.2 \mathrm{~mm})$ and median $(H P=110.6 \mathrm{~mm}, \mathrm{RP}=103.0 \mathrm{~mm})$ values reflect lower RP dryseason totals (Fig. 6h, Table 2). The RP dry-season rain day counts are marginally lower than those for the HP, reflected by the plotted IQR (Fig. 6i), and mean $(\mathrm{HP}=29$ days, $\mathrm{RP}=27$ days) and median ( $\mathrm{HP}=30$ days, $\mathrm{RP}=27$ days) values (Table 2$)$. The HP dry-season daily rainfall rate was only slightly higher than that for the RP, as demonstrated by the plotted IQR, and mean $\left(\mathrm{HP}=4.2 \mathrm{~mm} \cdot \mathrm{d}^{-1}, \mathrm{RP}=4.1 \mathrm{~mm} \cdot \mathrm{d}^{-1}\right)$ and median $\left(\mathrm{HP}=3.8 \mathrm{~mm} \cdot \mathrm{d}^{-1}, \mathrm{RP}=3.7 \mathrm{~mm} . \mathrm{d}^{-1}\right)$ values $(\mathrm{Fig} .6 \mathrm{j}$, Table 2).

\section{Discussion}

Using the SAAO meteorological record, we present the longest station-based rainfall seasonality record for Cape Town, within South Africa's WRZ. This longterm record is particularly valuable for trend analysis as trend evolution can be explored meaningfully and in detail as has been done here using the SQMKT (Ndebele et al. 2020), and the influence of interdecadal variability on trend magnitude and direction is limited compared to that for shorter records (e.g. Roffe et al. 2021a). While this is the case, it is important to acknowledge that the quasi-periodicities evident from the SQMKT plots can make detection and interpretation of long-term trends difficult, thus necessitating consideration of trend evolution for long-term records (Wolski et al. 2021). Although we do not further explore these periodicities, as this is beyond our paper scope, these periodicities, especially for the wet- and dry-season totals, would likely be similar to those detected by Dieppois et al. (2016), Ndebele et al. (2020) and Wolski et al. (2021). Nevertheless, our results reflect that rainfall seasonality, expressed here by variables measuring the degree of seasonality and the duration, intensity, magnitude and timing of wet- and dry-season rainfall, has, for $1841-2020$, undergone a significant change for some of the variables considered. Note that the rainfall seasonality trends quantified here tentatively extend across the southwestern Cape region, containing Cape Town's supply dams (Fig. 1). This is argued based on results from Wolski et al. (2021), as trends for stations across the southwestern Cape region they defined, based on interannual rainfall variability patterns, are largely consistent, particularly in direction, throughout the various temporal periods they considered. As rainfall seasonality characteristics represent surface responses of weather systems (Lennard and Hegerl

Page 9/19 
2015), the changes quantified here are likely largely driven by weather system changes which are primarily driven by hemispheric-scale atmospheric circulation changes (Sousa et al. 2018; Burls et al. 2019). As our aim is only to explore how Cape Town's rainfall seasonality characteristics have changed during 1841-2020, we only tentatively discuss trend drivers.

Results from the ratio and percentile-based seasonality metric demonstrate strong agreement, reflecting a trend towards stronger WRZ conditions. This trend and agreement, evident from the score and wet-season (and dry-season) length trend directions and the SQMKT results thereof, exists throughout 1841-2020, though trends are stronger for 1933-2020. The changes in seasonality timing are thus a degree of seasonality increase, with scores tending away from zero, and a wet-season (dry-season) shortening (lengthening); a result consistent with observed and projected trends for the southwestern Cape (Li et al. 2016; Pascale et al. 2016; du Plessis and Schloms 2017; Dunning et al. 2018; Jury 2020; Ndebele et al. 2020; Wolski et al. 2021). Although rainfall declines detected, across the southwestern Cape, for spring (September-November) or months therein are argued to reflect earlier end-dates (du Plessis and Schloms 2017; Jury 2020; Ndebele et al. 2020), our results do not necessarily reflect end-date changes during 1841-2020, but instead the end-dates varied substantially; this variability has seemingly increased for recent decades. The trend in wet-season duration is thus primarily driven by later (earlier) wet-season (dry-season) start-dates (end-dates), which is near-significant for 1841-2020 and significant for 1933-2020. This is supported by our comparative analysis, and by later wet-season start-date and autumn (March-May) drying trends quantified for recent decades, from 1980, for Cape Town and the southwestern Cape, respectively (Mahlalela et al. 2019; Roffe et al. 2021a; Wolski et al. 2021). Considering drivers behind the wet-season (and dry-season) timing changes, it is likely that the later start-date trend is linked to increases in the frequency of post-frontal SAA ridging high-pressure systems recorded for 1979-2017, which is likely driven by Hadley cell expansion and descending branch intensification, especially in Autumn (Grise et al. 2018; Burls et al. 2019; Mahlobo et al. 2019). This is supported by Mahlalela et al. (2019) who link dry early winter (April-May) periods, which coincide with the timing of most SAAO start-dates, to an increased frequency of SAA ridging high-pressure systems, across the southwestern Cape. Further, Mahlalela et al. (2019) note that the driest winters during 1979-2017 occurred after 2000, which corresponds to a significant later start-date trend, from 2007 according to our SQMKT results.

Our results consistently demonstrate that the wet-season has become drier. Wet-season totals have declined since $\sim 1881$, or $~ 1892$ at least, and our comparative analysis results demonstrate that this reduction is one of the most distinct rainfall seasonality changes to have occurred during $1841-2020$. The winter wet-season drying trend, being the strongest direct driver of the 2015-2017 'Day Zero' drought, is among the most robustly projected rainfall changes in response to anthropogenically induced climate change (Dunning et al. 2018; Mahlalela et al. 2019; Pascale et al. 2020; Lim Kam Sian et al. 2021), and it is significant for recent decades for Cape Town (Roffe et al. 2021a). Numerous studies have attributed this drying trend to an observed poleward expansion of the subtropical high-pressure belt and migration of the westerlies (Sousa et al. 2018; Burls et al. 2019; Mahlalela et al. 2019), and it is very likely that these trends will persist until the end of the century, at least (Engelbrecht et al. 2009; Chavaillaz et al. 2013; Fahad et al. 2020). Results from literature suggest these trends have manifested as a decline in the frequency of winter rain-bearing circulation features, cold fronts in particular, with an increased frequency of dry circulation features such as SAA ridging high-pressure systems (Lennard and Hegerl 2015; Sousa et al. 2018; Burls et al. 2019; Mahlalela et al. 2019; Odoulami et al. 2021). Burls et al. (2019) additionally demonstrate that, due to increased post-frontal SAA ridging, the duration and intensity of cold front rainfall events has declined since $\sim 1979$. This is linked to a long-term decline, since $\sim 1900$, in rain day counts and a more recent decline, since $\sim 2010$, in rainfall intensity for the April-September winter wet-season (Burls et al. 2019). This is supported by our results of a decline in wet-season rain day counts throughout 18412020, but more prominently since 1933, and of a more recent daily rainfall rate decline since 2009 .

Evidently, the dry-season has also become drier. This trend is significant from 1933, or more specifically from 1955/56, and our comparative analysis results robustly reflect reduced RP dry-season totals. Our results also reflect a significant decline, since $\sim 1949 / 50$ at the least, in the dry-season rain day counts and during recent decades, from $\sim 1996 / 97$ or $\sim 2001 / 02$ at least, the daily rainfall rate has also declined. Thus, together with the wet-season rainfall decline, the dry-season rainfall decline has contributed to an increasing duration, frequency and intensity of drought periods for Cape Town and the southwestern Cape region recorded since 1985 (Botai et al. 2017; De Kock et al. 2021). Notably, dry-season rainfall has received limited research attention, despite its importance in mitigating drought impacts through a contribution to increasing dam levels, especially from large dry-season rainfall events (De Kock et al. 2021; Wolski et al. 2021). Despite this, much evidence exists for long-term drying during the dry-season, or months therein (Ndebele et al. 2020; De Kock et al. 2021; Wolski et al. 2021). Although limited evidence exists for changes in the dry-season rain day counts and daily rainfall rate, for Cape Town and the southwestern Cape Mackellar et al. (2014) demonstrate declines in summer (December-February) rain day counts for 1960-2010. Considering drivers behind the dry-season rainfall changes, it is likely that these are consistent with the hemispheric-scale drivers of wet-season rainfall changes. Not only is this suggested by De Kock et al. (2021) and Wolski et al. (2021), but similar patterns of cyclicity across our SQMKT wet- and dry-season results reflects similar trend drivers. Thus, the dry-season trends are similarly linked to a stronger and farther south and expanded SAA, induced by Hadley cell expansion and descending branch intensification (Sousa et al. 2018; Mahlobo et al. 2019; Jury 2020; De Kock et al. 2021; Wolski et al. 2021). Declines in the rainfall contributions from atmospheric rivers and cut-off lows are detected for dry-season months from 1979/80 and are similarly consistent with recorded poleward deviations of the westerlies (De Kock et al. 2021). Rainfall declines can also be linked to an observed summer increase in dry circulation types associated with subsidence (Lennard and Hegerl 2015; Jury 2020; Odoulami et al. 2021). Again, it should be highlighted that these hemispheric dynamics, identified as drivers behind dry-season rainfall changes, are expected to change in a similar manner in the future (Engelbrecht et al. 2009; Chavaillaz et al. 2013; Fahad et al. 2020).

Strong consistency between the trend, SQMKT and comparative analysis results provides corroboration for the nature of seasonality trends quantified here, while strong agreement with seasonality projections, especially for recent decades, suggests these trends may continue (Pascale et al. 2016; Dunning et al. 2018). The consistency and robustness of observed and projected trajectories of the Hadley cell and mid-latitude westerlies (Yin et al. 2005; Lu et al. 2007; Chavaillaz et al. 2013; Nguyen et al. 2015; Sousa et al. 2018; Mahlobo et al. 2019; Fahad et al. 2020), similarly suggests that trends detected for recent decades are likely to continue. Thus, coupled with increasing temperatures (Lakhraj-Govender et al. 2017), our results of drier conditions during the wet- and dry-season, which is supported by copious evidence from the literature, demonstrates that Cape Town will likely experience increasing water stress. As such, water resource management and planning need to focus on reducing the risks and vulnerability associated with changing rainfall regimes. Water conservation

Page $10 / 19$ 
and management strategies, such as recycling, water supply diversification (e.g. desalination and groundwater extraction), ecosystem-based approaches (e.g. removal of invasive vegetation, ensuring more water reaches dams) and awareness initiatives, implemented not only in response to the 2015-2017 'Day Zero' water crisis, but in general, must continue and be improved on (e.g. Booysen et al. 2019).

As for any study, there are limitations, and here these arise from the use of long-term data. For the SAAO record, limitations hinder establishment of dataset homogeneity and include no existing reference series for 1841-1899 and little metadata found for instrumental type, changes in instrumentation and location, and recording methods and times (Lakhraj-Govender et al. 2017; Picas et al. 2019). The rainfall record has, for the most part, been based on manually derived daily rain gauge readings from the SAAO gardens (Ndebele et al. 2020), however, during 2009 an automatic station was installed (Glass 2018). For the temperature record, several changes in recording times and methods occurred throughout 1841-2020 (Lakhraj-Govender et al. 2017; Picas and Grab 2020). Recent records, from 2009, are captured hourly by automatic stations, whereas earlier records were manually captured at varying times (Lakhraj-Govender et al. 2017; Picas and Grab 2020). With no station relocation records, it can be assumed that the SAAO monitoring station has remained in the same location (Lakhraj-Govender et al. 2017; Ndebele et al. 2020; Picas and Grab 2020). Thus, the main limitation, besides that of the data gap for 1900-1933, underlying our results is that our records were not homogenized to account for changes in instrumental type and recording times. Records for 1841-1899 are comparable to recent records, which increases confidence in the reliability of these (Ndebele et al. 2020; Picas and Grab 2020), and results from LakhrajGovender et al. (2017) reflect little change in trend magnitude and no change in trend direction for the SAAO 1933-2013 temperature series following homogenization adjustments. Thus, this improves confidence in our results.

\section{Conclusion}

Based on the longest record of rainfall seasonality characteristics for Cape Town within South Africa's WRZ, we demonstrate value in using long-term records to explore rainfall regime trends in detail. This is particularly evident from our SQMKT application which demonstrates a complex temporal pattern for Cape Town's rainfall seasonality characteristics for 1841-2020 and reveals much value in exploring trend evolution, beyond simply considering overall trend magnitudes and directions for arbitrarily defined periods. Together with evidence from projected rainfall seasonality trends for Cape Town, which correspond to our findings, we provide an example of the likely rainfall seasonality patterns to occur across Cape Town in future decades. Our findings particularly highlight trends towards shorter, later starting and drier wet-seasons together with longer and drier dry-seasons, and have important implications for rainfall sensitive activities. Thus, our findings can contribute to water resource management strategies for Cape Town and the broader southwestern Cape region; a region already vulnerable to rainfall regime changes. If scientific evidence is considered properly for such strategies, then the impacts of future extreme multiyear droughts, which are projected with much robustness (Otto et al. 2018; Pascale et al. 2020), may be mitigated considerably.

\section{Declarations}

\section{Acknowledgments}

We thank the South African Weather Service for providing weather station data for 1933-2020 and Nothabo Ndebele for providing cleaned and quality controlled daily rainfall data for 1841-1899 for the South African Astronomical Observatory.

\section{Funding information}

SJR acknowledges funding from the University of the Witwatersrand Faculty of Science Research Committee. JMF is funded by the DSI-NRF Centre of Excellence for Palaeoscience.

\section{Conflict of interest}

The authors declare no conflict of interest.

\section{Availability of data}

Data for 1841-1899 can be obtained by direct request to the authors. Data for 1933-2020 can be obtained through a direct request to the South African Weather Service (SAWS).

\section{Code availability}

Not applicable.

\section{Author contributions}

SJR, JS and JMF conceptualised the topic of this paper. SJR conducted all statistical analyses with input from JS and JMF. SJR compiled the manuscript, and JS and JMF provided input on the various drafts.

\section{Consent for publication}

All authors agree to the publication of this manuscript.

\section{Ethics approval}

Not applicable 


\section{Consent to participate}

Not applicable

\section{References}

1. Aguilar E, Auer I, Brunet M, Peterson TC, Wieringa J (2003) Guidance on metadata and homogenization, 1186. World Meteorological Organization Technical Document no, p 53

2. Beaulieu C, Chen J, Sarmiento JL (2012) Change-point analysis as a tool to detect abrupt climate variations. Philos T R Soc A 370(1962):1228-1249. https://doi.org/10.1098/rsta.2011.0383

3. Blamey RC, Ramos AM, Trigo RM, Tomé R, Reason CJC (2018) The influence of atmospheric rivers over the South Atlantic on winter rainfall in South Africa. J Hydrometeorol 19(1):127-142. https://doi.org/10.1175/JHM-D-17-0111.1

4. Blamey R, Reason CJC (2007) Relationships between Antarctic sea-ice and South African winter rainfall. Clim Res 33:183-193. https://doi.org/10.3354/cr033183

5. Booysen MJ, Rpunda C, Visser M (2019) Results from a water-saving maintenance campaign at Cape Town schools in the run-up to Day Zero. Sustain Cities Soc 50:101639. https://doi.org/10.1016/j.scs.2019.101639

6. Botai CM, Botai JO, de Wit JP, Ncongwane KP, Adeola AM (2017) Drought characteristics over the Western Cape province, South Africa. Water 9(11):876. https://doi.org/10.3390/w9110876

7. Burls NJ, Blamey RC, Cash BA, Swenson ET, Fahad M, Bopape MJM, Straus DM, Reason CJ (2019) The Cape Town "Day Zero" drought and Hadley cell expansion. Npj Clim Atmos Sci 2:27. https://doi.org/10.1038/s41612-019-0084-6

8. Chavaillaz Y, Codron F, Kageyama M (2013) Southern westerlies in LGM and future (RCP 4.5) climates. Clim Past 9(2):517-524. https://doi.org/10.5194/cp-9-517-2013

9. De Kock WM, Blamey RC, Reason CJC (2021) Large summer rainfall events and their importance in mitigating droughts over the South Western Cape, South Africa. J Hydrometeorol 22(3):587-599. https://doi.org/10.1175/JHM-D-20-0123.1

10. Dieppois B, Pohl B, Rouault M, New M, Lawler D, Keenlyside N (2016) Interannual to interdecadal variability of winter and summer southern African rainfall, and their teleconnections. J Geophys Res-Atmos 121(11):405-442. https://doi.org/10.1002/2015JD024576

11. du Plessis JA, Schloms B (2017) An investigation into the evidence of seasonal rainfall pattern shifts in the Western Cape, South Africa. J S Afr Inst Civ Eng 59(4):47-55. http://dx.doi.org/10.17159/2309-8775/2017/v59n4a5

12. Dunning CM, Black EC, Allan RP (2018) Later wet seasons with more intense rainfall over Africa under future climate change. J Clim 31(23):9719-9738. https://doi.org/10.1175/JCLI-D-18-0102.1

13. Durre I, Menne MJ, Gleason BE, Houston TG, Vose RS (2010) Comprehensive automated quality assurance of daily surface observations. J Appl Meteorol Climatol 49(8):1615-1633. https://doi.org/10.1175/2010JAMC2375.1

14. Dyson LL (2009) Heavy daily-rainfall characteristics over the Gauteng Province. Water SA 35(5):627-638. https://doi.org/10.4314/wsa.v35i5.49188

15. Engelbrecht FA, McGregor JL, Engelbrecht CJ (2009) Dynamics of the Conformal-Cubic Atmospheric Model projected climate-change signal over southern Africa. Int J Climatol 29(7):1013-1033. https://doi.org/10.1002/joc.1742

16. Fahad AA, Burls NJ, Strasberg Z (2020) How will southern hemisphere subtropical anticyclones respond to global warming? Mechanisms and seasonality in CMIP5 and CMIP6 model projections. Clim Dyn 55:703-718. https://doi.org/10.1007/s00382-020-05290-7

17. Favre A, Hewitson B, Lennard C, Cerezo-Mota R, Tadross M (2013) Cut-off lows in the South Africa region and their contribution to precipitation. Clim Dyn 41:2331-2351. https://doi.org/10.1007/s00382-012-1579-6

18. George J, Athira P (2020) Long-term changes in climatic variables over the Bharathapuzha river basin, Kerala, India. Theor Appl Climatol 142:269-286. https://doi.org/10.1007/s00704-020-03255-8

19. Glass IS (2018) The Royal Observatory rainfall records. Mon Notes Astron Soc S Afr 77(5-6):77-80. https://hdl.handle.net/10520/EJC-1342b9d7f0

20. Grise KM, Davis SM, Staten PW, Adam O (2018) Regional and seasonal characteristics of the recent expansion of the Tropics. J Clim 31(17):6839-6856. https://doi.org/10.1175/JCLI-D-18-0060.1

21. Hekmatzadeh AA, Kaboli S, Torabi Haghighi A (2020) New indices for assessing changes in seasons and in timing characteristics of air temperature. Theor Appl Climatol 140:1247-1261. https://doi.org/10.1007/s00704-020-03156-w

22. Jury MR (2020) Climate trends in the Cape Town area, South Africa. Water SA 46(3):438-447. https://doi.org.10.17159/wsa/2020.v46.i3.8654

23. Lakhraj-Govender R, Grab S, Ndebele NE (2017) A homogenized long-term temperature record for the Western Cape Province in South Africa: $1916-2013$. Int J Climatol 37(5):2337-2353. https://doi.org/10.1002/joc.4849

24. Lennard C, Hegerl G (2015) Relating changes in synoptic circulation to the surface rainfall response using self-organising maps. Clim Dyn 44:861-879. https://doi.org/10.1007/s00382-014-2169-6

25. Li X, Hu ZZ, Jiang X, Li Y, Gao Z, Yang S, Zhu J, Jha B (2016) Trend and seasonality of land precipitation in observations and CMIP5 model simulations. Int J Climatol 36(11):3781-3793. https://doi.org/10.1002/joc.4592

26. Lim Kam Sian KTC, Wang J, Ayugi BO, Nooni IK, Ongoma V (2021) Multi-Decadal Variability and Future Changes in Precipitation over Southern Africa. Atmosphere 12(6):742. https://doi.org/10.3390/atmos12060742

Page $12 / 19$ 
27. Lu J, Vecchi GA, Reichler T (2007) Expansion of the Hadley cell under global warming. Geophys Res Lett 34(6):L06805. https://doi.org/10.1029/2006GL028443

28. MacKellar N, New M, Jack C (2014) Observed and modelled trends in rainfall and temperature for South Africa: 1960-2010. S Afr J Sci 110(7-8):1-13. https://doi.org/10.1590/sajs.2014/20130353

29. Mahlalela PT, Blamey RC, Reason CJC (2019) Mechanisms behind early winter rainfall variability in the southwestern Cape, South Africa. Clim Dyn 53:21-39. https://doi.org/10.1007/s00382-018-4571-y

30. Mahlobo DD, Ndarana T, Grab S, Engelbrecht F (2019) Integrated climatology and trends in the subtropical Hadley cell, sunshine duration and cloud cover over South Africa. Int J Climatol 39(4):1805-1821. https://doi.org/10.1002/joc.5917

31. Muller M (2018) Cape Town's drought: don't blame climate change. Nature 559:174-176. https://doi.org/10.1038/d41586-018-05649-1

32. Ndarana T, Mpati S, Bopape MJ, Engelbrecht F, Chikoore H (2021) The flow and moisture fluxes associated with ridging South Atlantic Ocean anticyclones during the subtropical southern African summer. Int J Climatol 41(S1):E1000-E1017. https://doi.org/10.1002/joc.6745

33. Ndebele NE, Grab S, Turasie A (2020) Characterizing rainfall in the south-western Cape, South Africa: 1841-2016. Int J Climatol 40(4):1992-2014. https://doi.org/10.1002/joc.6314

34. Nguyen H, Lucas C, Evans A, Timbal B, Hanson L (2015) Expansion of the southern hemisphere Hadley cell in response to greenhouse gas forcing. J Clim 28(20):8067-8077. https://doi.org/10.1175/JCLI-D-15-0139.1

35. Odoulami RC, Wolski P, New M (2021) A SOM-based analysis of the drivers of the 2015-2017 Western Cape drought in South Africa. Int J Climatol 41(S1):E1518-E1530. https://doi.org/10.1002/joc.6785

36. Omar SA, Abiodun BJ (2020) Characteristics of cut-off lows during the 2015-2017 drought in the Western Cape, South Africa. Atmos Res $235: 104772$. https://doi.org/10.1016/j.atmosres.2019.104772

37. Otto FE, Wolski P, Lehner F, Tebaldi C, van Oldenborgh GJ, Hogesteeger S, Singh R, Holden P, Fučkar NS, Odoulami RC, New M (2018) Anthropogenic influence on the drivers of the Western Cape drought 2015-2017. Environ Res Lett 13(12):124010. https://doi.org/10.1088/1748-9326/aae9f9

38. Pascale S, Kapnick SB, Delworth TL, Cooke WF (2020) Increasing risk of another Cape Town "Day Zero" drought in the 21st century. Proc Natl Acad Sci USA 117(47):29495-29503. https://doi.org/10.1073/pnas.2009144117

39. Philippon N, Rouault M, Richard Y, Favre A (2012) The influence of ENSO on winter rainfall in South Africa. Int J Climatol 32(15):2333-2347. https://doi.org/10.1002/joc.3403

40. Picas J, Grab S (2020) Potential impacts of major nineteenth century volcanic eruptions on temperature over Cape Town, South Africa: 1834-1899. Clim Change 159:523-544. https://doi.org/10.1007/s10584-020-02678-6

41. Picas J, Grab S, Allen R (2019) A 19th century daily surface pressure series for the southwestern Cape region of South Africa: 1834-1899. Int J Climatol 39(3):1404-1414. https://doi.org/10.1002/joc.5890

42. Reason CJC, Allan RJ, Lindesay JA, Ansell TJ (2000) ENSO and climatic signals across the Indian Ocean Basin in the global context: part I, interannual composite patterns. Int J Climatol 20(11):1285-1327. https://doi.org/10.1002/1097-0088(200009)20:11<1285::AID-JOC536>3.0.CO;2-R

43. Reason CJC, Jagadheesa D (2005) Relationships between South Atlantic SST variability and atmospheric circulation over the South African region during austral winter. J Clim 18(16):3339-3355. https://doi.org/10.1175/JCLI3474.1

44. Reason CJC, Rouault M (2005) Links between the Antarctic Oscillation and winter rainfall over western South Africa. Geophys Res Lett 32(7). https://doi.org/10.1029/2005GL022419

45. Reason CJC, Rouault M, Melice JL, Jagadheesha D (2002) Interannual winter rainfall variability in SW South Africa and large scale ocean-atmosphere interactions. Meteorol Atmos Phys 80:19-29. https://doi.org/10.1007/s007030200011

46. Roffe SJ, Fitchett JM, Curtis CJ (2019) Classifying and mapping rainfall seasonality in South Africa: a review. S Afr Geogr J 101(2):158-174. https://doi.org/10.1080/03736245.2019.1573151

47. Roffe SJ, Fitchett JM, Curtis CJ (2020) Determining the utility of a percentile-based wet-season start- and end-date metric across South Africa. Theor Appl Climatol 140:1331-1347. https://doi.org/10.1007/s00704-020-03162-y

48. Roffe SJ, Fitchett JM, Curtis CJ (2021a) Investigating rainfall seasonality changes across South Africa: 1987-2016. Int J Climatol 41(S1):E2031-E2050. https://doi.org/10.1002/joc.6830

49. Roffe SJ, Fitchett JM, Curtis CJ (2021b) Quantifying rainfall seasonality across South Africa on the basis of the relationship between rainfall and temperature. Clim Dyn 56:2431-2450. https://doi.org/10.1007/s00382-020-05597-5

50. Sneyers R (1991) On the statistical analysis of series of observations. World Meteorological Organization Technical Document no 143:192

51. Sousa PM, Blamey RC, Reason CJ, Ramos AM, Trigo RM (2018) The 'Day Zero' Cape Town drought and the poleward migration of moisture corridors. Environ Res Lett 13(12):124025. https://doi.org/10.1088/1748-9326/aaebc7

52. van der Walt AJ, Fitchett JM (2020) Statistical classification of South African seasonal divisions on the basis of daily temperature data. S Afr J Sci 116(9-10):1-15. https://doi.org/10.17159/sajs.2020/7614

53. Wolski P (2018) How severe is Cape Town's “Day Zero”. drought? Significance 15(2):24-27. https://doi.org/10.1111/j.1740-9713.2018.01127.x

54. Wolski P, Conradie S, Jack C, Tadross M (2021) Spatio-temporal patterns of rainfall trends and the 2015-2017 drought over the winter rainfall region of South Africa. Int J Climatol 41(S1):1303-1319. https://doi.org/10.1002/joc.6768

55. Yin JH (2005) A consistent poleward shift of the storm tracks in simulations of 21st century climate. Geophys Res Lett 32(18):1-4.

https://doi.org/10.1029/2005GL023684

Page $13 / 19$ 


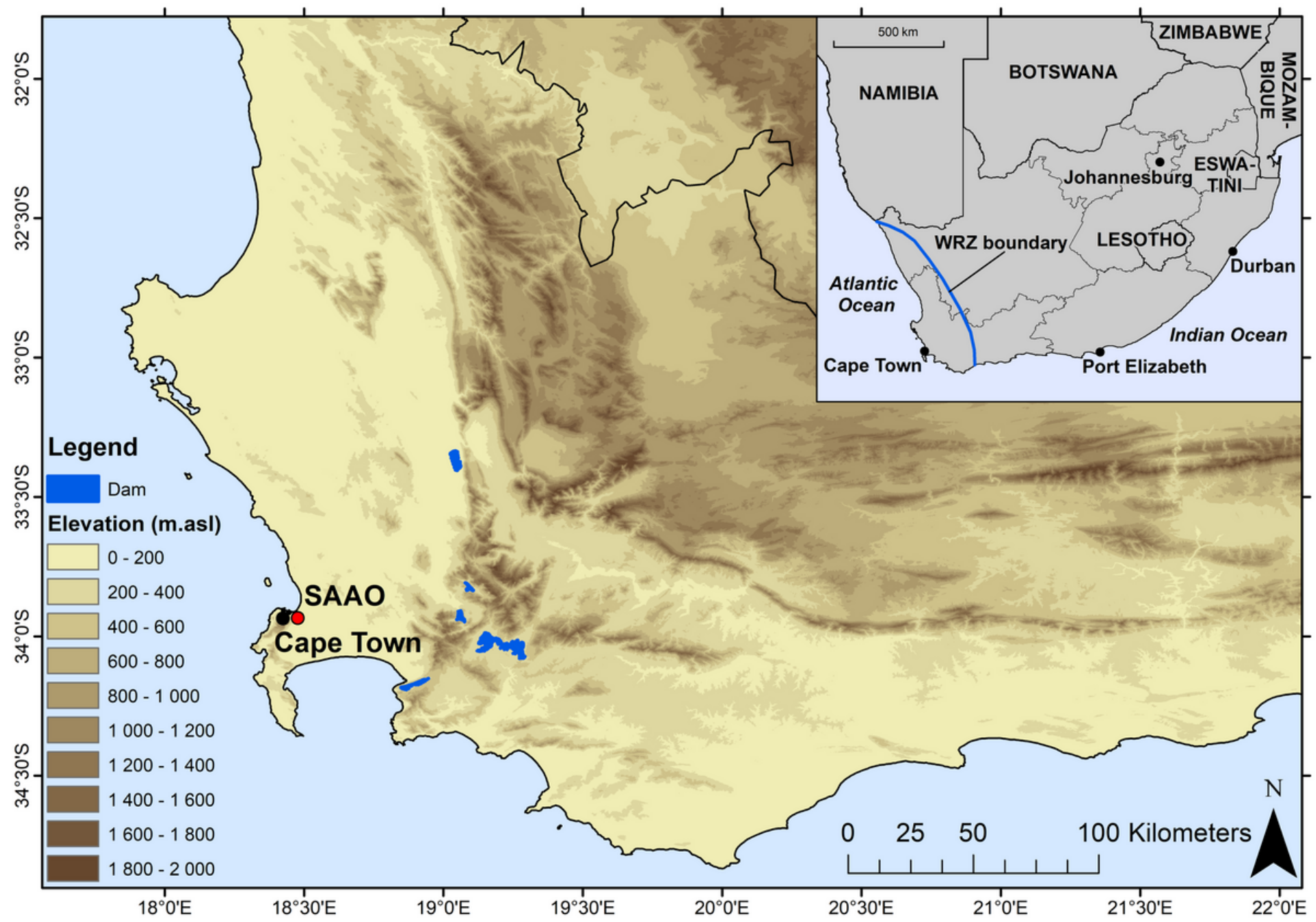

Figure 1

Location of the South African Astronomical Observatory (SAAO) meteorological station, at $33^{\circ} 56^{\prime} 4^{\prime \prime} \mathrm{S}, 18^{\circ} 28^{\prime} 38.3^{\prime \prime} \mathrm{E}$ and $12 \mathrm{~m}$.asl, in relation to the Cape Town City center within the Western Cape of South Africa, and within the winter rainfall zone (WRZ estimated boundary is from Roffe et al. 2021b). The topography across the region and Cape Town's main water supply dams are also depicted. 

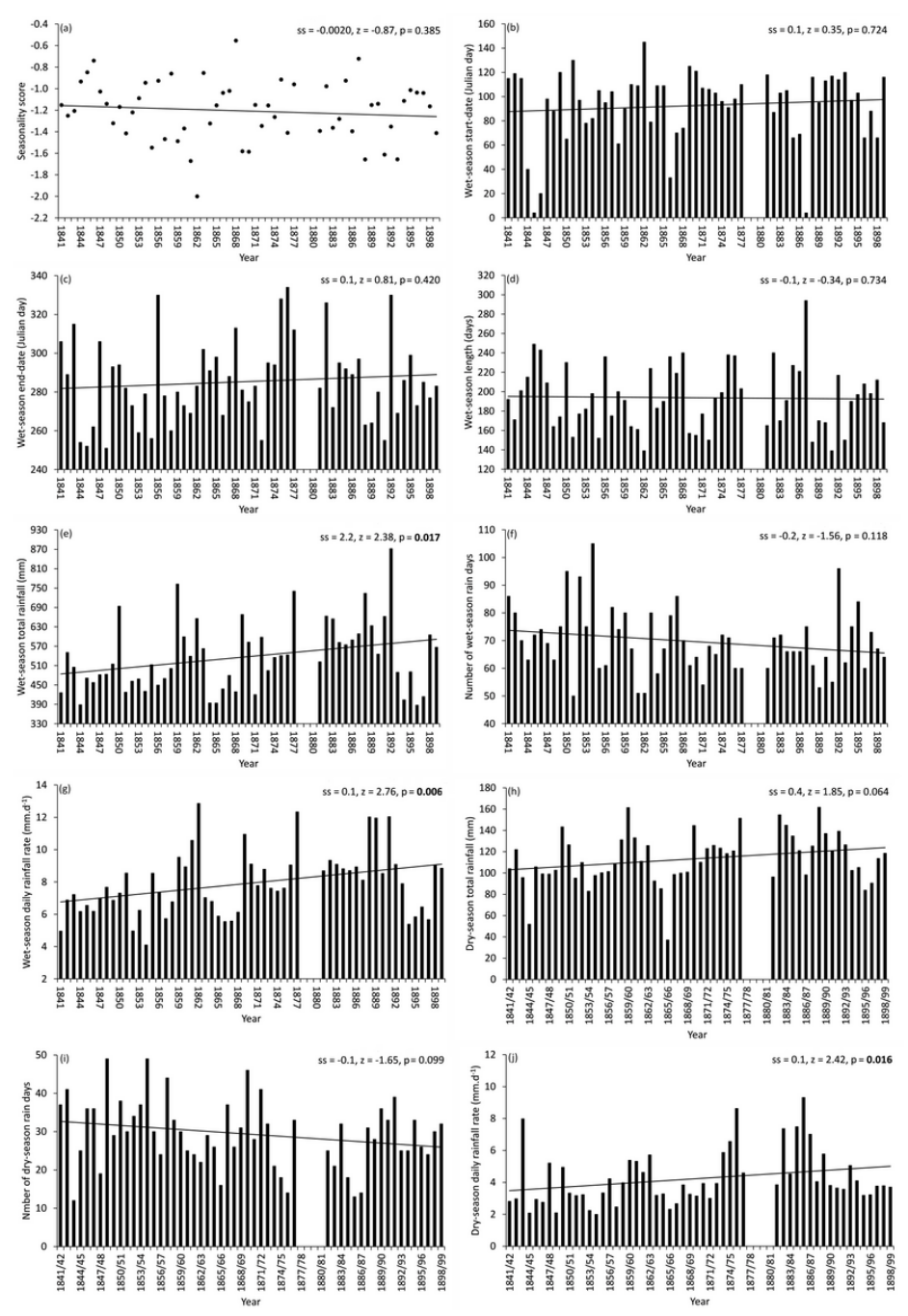

\section{Figure 2}

Time series and corresponding linear trend lines of (a) seasonality scores, (b) wet-season start-dates, (c) wet-season end-dates, (d) wet-season lengths, (e) wet-season total rainfall, (f) number of wet-season rain days, (g) wet-season daily rainfall rate, (h) dry-season total rainfall, (i) dry-season number of rain days and (j) dry-season daily rainfall rate for 1841-1899 (or 1841/42-1898/99 for the dry-season variables). Here, ss represents the Sen's slope, z represents the Mann-Kendall statistic and $p$ represents the Mann-Kendall test $p$ value. Statistically significant $p$ values $(p<0.05)$ are denoted in bold. 

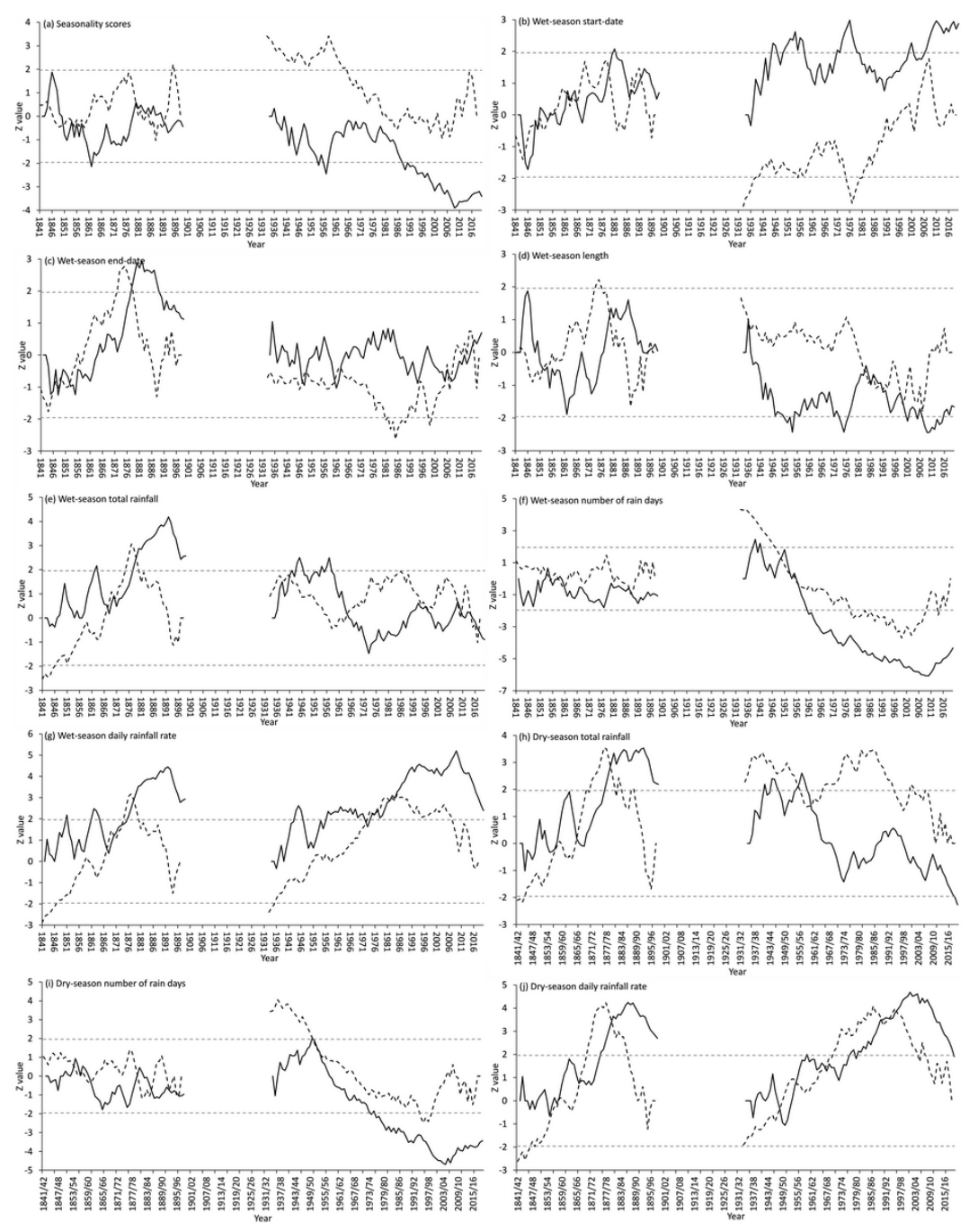

\section{Figure 3}

Sequential Mann-Kendall test of (a) seasonality scores, (b) wet-season start-dates, (c) wet-season end-dates, (d) wet-season lengths, (e) wet-season total rainfall, (f) number of wet-season rain days, (g) wet-season daily rainfall rate, (h) dry-season total rainfall, (i) dry-season number of rain days and (j) dryseason daily rainfall rate for 1841-2020 (or 1841/42-2019/20 for the dry-season variables). Solid black lines represent the U(t) values, dashed black lines represent the $U^{\prime}(t)$ results and horizontal dashed grey lines depict the $z$ value confidence intervals at $+/-1.96$. 

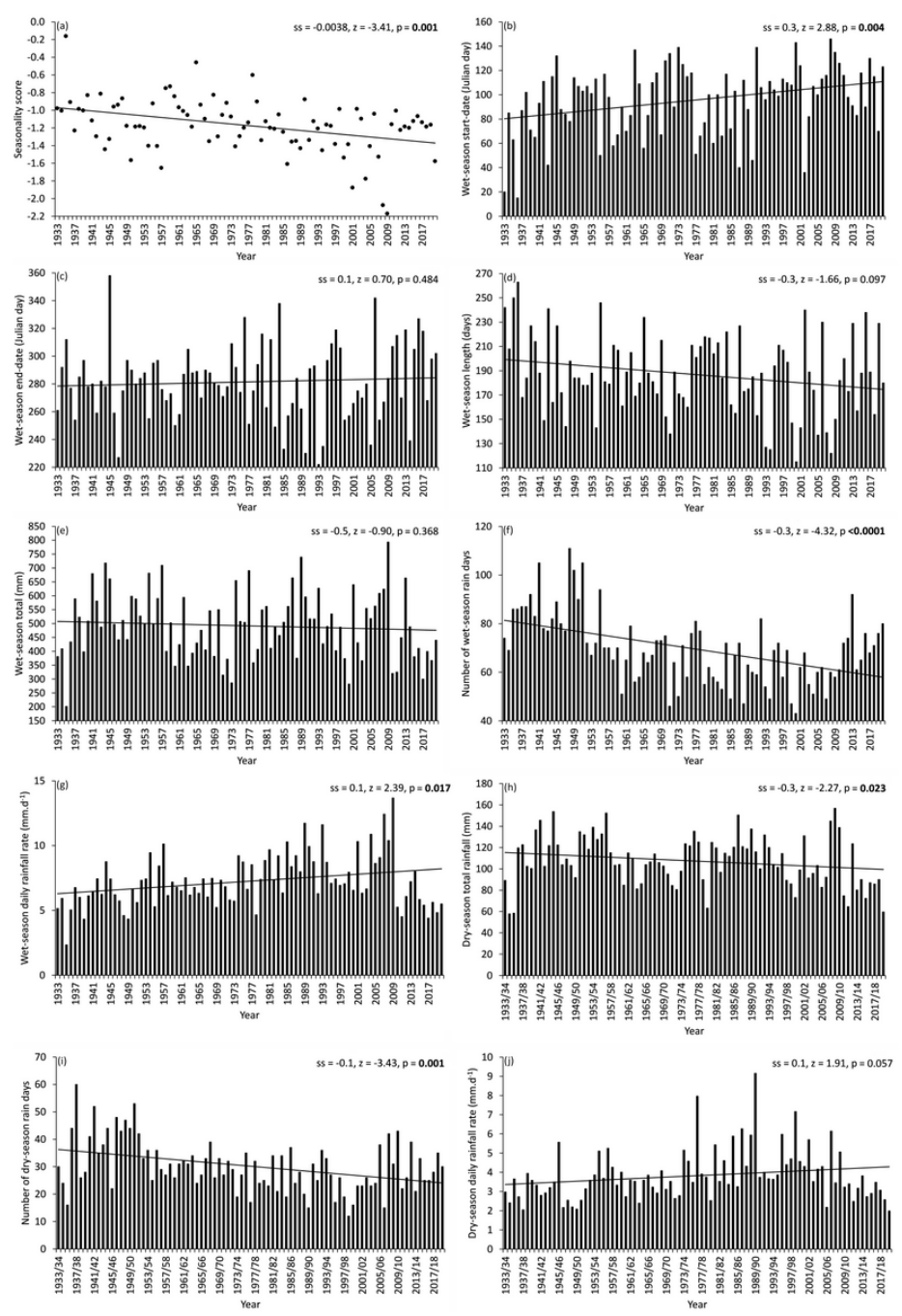

Figure 4

Time series and corresponding linear trend lines of (a) seasonality scores, (b) wet-season start-dates, (c) wet-season end-dates, (d) wet-season lengths, (e) wet-season total rainfall, (f) number of wet-season rain days, (g) wet-season daily rainfall rate, (h) dry-season total rainfall, (i) dry-season number of rain days and (j) dry-season daily rainfall rate for 1933-2020 (or 1933/34-2019/20 for the dry-season variables). Here, ss represents the Sen's slope, $z$ represents the Mann-Kendall statistic and $p$ represents the Mann-Kendall test $p$ value. Statistically significant $p$ values $(p<0.05)$ are denoted in bold. 

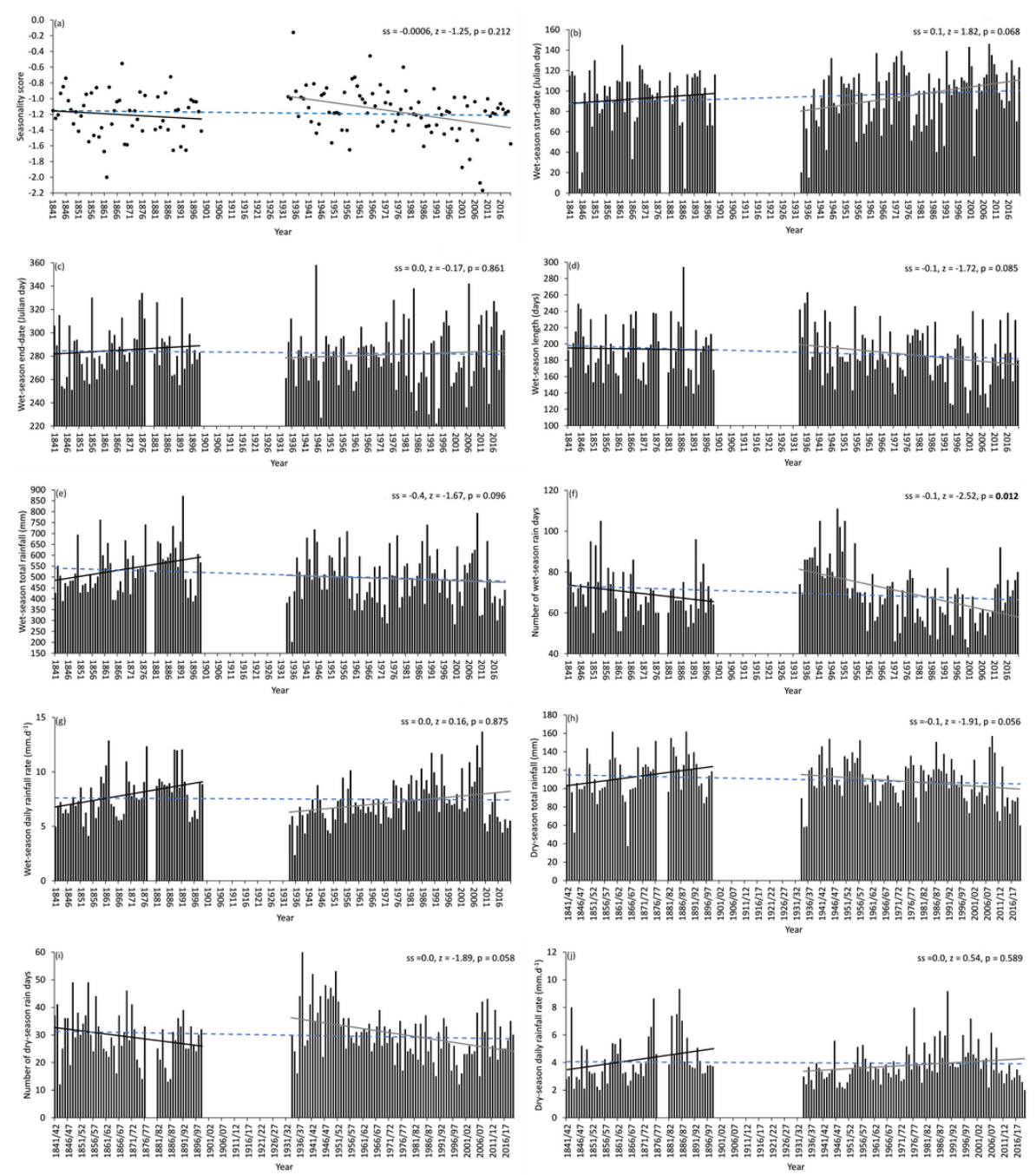

\section{Figure 5}

Time series and corresponding tentative linear trend lines of (a) seasonality scores, (b) wet-season start-dates, (c) wet-season end-dates, (d) wet-season lengths, (e) wet-season total rainfall, (f) number of wet-season rain days, (g) wet-season daily rainfall rate, (h) dry-season total rainfall, (i) dry-season number of rain days and (j) dry-season daily rainfall rate for 1841-2020 (or 1841/42-2019/20 for the dry-season variables; dashed blue line). Trendlines for 1841-1899 (or 1841/42-1898/99; solid black line) and 1933-2020 (or 1933/34-2019/20; solid grey line) are also plotted. Here, ss represents the Sen's slope, z represents the Mann-Kendall statistic and $p$ represents the Mann-Kendall test $p$ value. Statistically significant $p$ values $(p<0.05)$ are denoted in bold. 

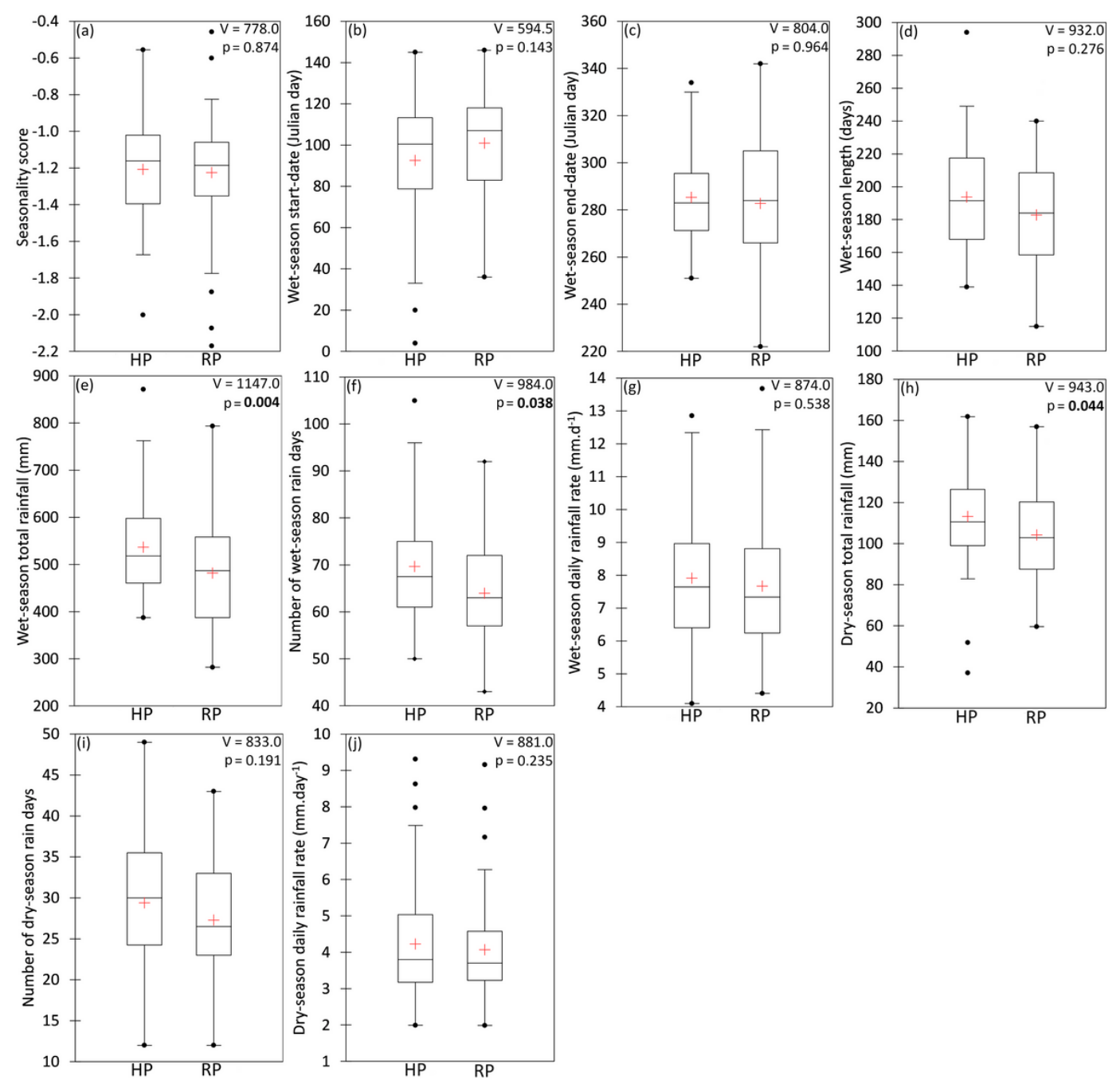

\section{Figure 6}

Boxplots comparing the statistical distribution of historical (1841-1899) and recent (1962-2020) period rainfall seasonality characteristics. The central lines represent median values and the red crosses represent mean values. Wilcoxon paired sample test ( $V$ value represents the test statistic) results are also depicted, where statistically significant $p$ values $(p<0.05)$ are denoted in bold. HP and RP denote boxplots for the historical and recent periods, respectively. 